\title{
Konrad Pawłowski
}

\section{Polityka Federacyjnej Republiki Jugosławii wobec konfliktu zbrojnego w Bośni i Hercegowinie (1992-1995)}

Czym jest polityka zagraniczna? To z pozoru oczywiste pytanie nasuwa jednak watpliwości. Większość badaczy zgadza się, że pojęcie to dotyczy procesu formułowania i realizacji celów przez uprawomocnione organy państwowe, które to cele wyrażaja żywotne interesy danego państwa i jego obywateli. Powszechnie przyjmuje się, że polityka zagraniczna realizowana jest za pomocą różnych środków, a więc stricte dyplomatycznych, ekonomicznych, militarnych czy kulturowych ${ }^{1}$.

Mimo to niekiedy niełatwe jest precyzyjne wskazanie, które fakty i wydarzenia stanowią treść polityki zagranicznej, a które nie powinny być zaliczane do tej kategorii działań państw. Analizując złożoność zakresu przedmiotowego pojęcia polityki zagranicznej, należy zatem dostrzec, iż wiele działań o charakterze wewnętrznym (np. wydatki na obronność państwa czy też ustawodawstwo dyskryminujące określone wspólnoty mniejszości) posiada określone międzynarodowe skutki (np. w postaci poczucia zagrożenia innych państw czy też międzynarodowej krytyki wobec dyskryminującej polityki wewnętrznej), mimo iż trudno zaliczyć je do polityki zagranicznej w ścisłym znaczeniu. Także niektóre działania o charakterze transgranicznym, jak wymiana gospodarcza, pomoc humanitarna czy polityka kulturalna, nie są często postrzegane jako część polityki zagranicznej, przynajmniej zaś w sytuacji, kiedy nie przypisuje się im określonego znaczenia lub skutku „politycznego”, zwiazanego z bezpieczeństwem państw oraz ich międzynarodowymi stosunkami politycznymi. Innymi słowy, ta sama pomoc humanitarna, adresowana do obywateli jednego kraju, może stanowić wyraz solidarności z potrzebujacymi, podczas gdy w innym przypadku jej udzielenie może posiadać silne implikacje polityczne, np. umocnienie sojuszu politycznego czy też poparcie dla władz tego państwa². Oczywiste pozostaje, iż wsparcie

1 Szerzej zob.: Z.J. Pietraś, Dyplomatyczna misja specjalna jako instytucja prawa międzynarodowego, Lublin 1978, s. 7-26; J. Sutor, Prawo dyplomatyczne i konsularne, Warszawa 2006, s. 29-31; B. Surmacz, Służba dyplomatyczna i konsularna, [w:] Międzynarodowe stosunki polityczne, red. nauk. M. Pietraś, Lublin 2006, s. 169-171; J.S. Nye, Soft Power. Jak osiagnać sukces w polityce światowej, Warszawa 2007, s. 24-28, 34-48.

2 T.B. Millar, On Writing about Foreign Policy, [w:] International Politics and Foreign Policy. A Reader in Research and Theory, ed. J.N. Rosenau, London-New York 1969, s. 57-64. 
ekonomiczne udzielone Jugosławii przez państwa Zachodu po wykluczeniu Jugosławii z Kominformu w 1948 r. nie miało jedynie wymiaru handlowego, lecz oparte było na politycznej „kalkulacji obustronnych korzyśsi” ${ }^{3}$.

Właściwa analiza polityki zagranicznej utrudniona jest także koniecznością dostrzeżenia i powiązania określonych faktów, które nie zawsze musza pozostawać zgodne z deklarowanymi oficjalnymi działaniami państw. Wpływ na politykę zagraniczną wywieraja także cechy osobowościowe decydentów, wśród których dostrzec można zarówno podejście idealistyczne, jak i postawy makiaweliczne, a nawet zachowania irracjonalne. Wszystko to powoduje, że analiza polityki zagranicznej nie jest zadaniem łatwym, tym bardziej że nie jest ona także wolna od subiektywizmu oceny danego badacza czy analityka ${ }^{4}$.

Oficjalna polityka Federacyjnej Republiki Jugosławii (FRJ) wobec wydarzeń, jakie miały miejsce w Bośni i Hercegowinie, wydaje się z pozoru jasna. Jak wskazywał w 1996 r. premier FRJ Radoje Kontić: „Federacyjna Republika Jugosławii [...] nie prowadziła wojny. Walki nie toczyły się na jej terytorium, choć wielu zagranicznych, a także rodzimych polityków usiłowało wciagnać nas

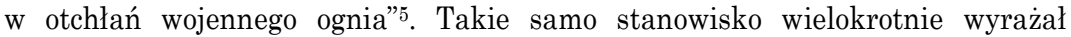
prezydent wchodzącej w skład FRJ Republiki Serbii Slobodan Milošević, deklarując, że konflikty na obszarze byłej Socjalistycznej Federacyjnej Republiki Jugosławii (SFRJ) wybuchły spontanicznie, zaś Jugosławia nie jest w stanie wojny z żadnym państwem i nie ma nic wspólnego z toczacymi się walkami ${ }^{6}$. Wiele wskazuje jednak, że mówiąc eufemistycznie, stanowisko to mijało się z prawda.

\section{Dylematy przyszłości, czyli... powrót do przeszłości}

Analizując koncepcje polityki wewnętrznej i zagranicznej SFRJ oraz FRJ w pierwszej połowie lat 90 . XX w., zasadne wydaje się wyodrębnienie czterech możliwych modeli tej polityki, tj.: kontynuację federacji jugosłowiańskiej, przekształcenie Jugosławii w konfederację, realizację idei „Wielkiej Serbii” oraz demokratyzację systemu politycznego, powiązana $\mathrm{z}$ liberalnymi reformami gospodarczymi i integracją ze strukturami euroatlantyckimi.

Wydarzenia w Jugosławii na przełomie lat 80. i 90. XX. w. zdominowane zostały przez pogłębiający się kryzys wewnętrzny o charakterze politycznym, jak

${ }^{3}$ W. Walkiewicz, Jugosławia. Byt wspólny i rozpad, Warszawa 2000, s. 186-192.

4 T.B. Millar, dz. cyt., s. 64.

${ }^{5}$ R. Bilski, Domagamy sie jednakowego traktowania stron konfliktu, „Rzeczpospolita”, 16 IV 1996, s. 7.

${ }^{6}$ S. Popovic, Miloševiç's Motiveless Malignancy, [w:] War and Change in the Balkans. Nationalism, Conflict and Cooperation, ed. B.K. Blitz, Cambridge 2006, s. 52 
i ekonomicznym, co w poważny sposób osłabiało poparcie społeczne dla modelu wspólnego federacyjnego państwa ${ }^{7}$. Paradoksalnie do pogłębienia kryzysu i dalszej dezintegracji SFRJ przyczyniła się częściowa demokratyzacja systemu. W $1990 \mathrm{r}$. odbyły się pierwsze wielopartyjne wybory do parlamentów republik, które doprowadziły do przejęcia władzy przez ugrupowania partyjne niechętne kontynuacji federacji w dotychczasowym kształcie. Podczas gdy nowe władze Słowenii i Chorwacji dążyły do dalszej decentralizacji państwa, decydenci w Serbii domagali się większej centralizacji SFRJ, co w pozostałych republikach postrzegano jako wyraz ukrytych dążeń do faktycznego podporządkowania pozostałych republik największej pod względem terytorialnym i demograficznym Republice Serbii oraz chęć powstrzymania naturalnego procesu demokratyzacji systemu politycznego, który rozpoczął się wraz z końcem „zimnej wojny”.

W drugiej połowie lat 80. XX w. scenę polityczną Serbii zdominowała postać charyzmatycznego Przewodniczącego Związku Komunistów Serbii S. Miloševicia, który zaczynał budować partyjną karierę, umiejętnie grając na coraz bardziej widocznych narodowych antagonizmach. W 1987 r., jako pierwszy z serbskich polityków, przemawiając do tłumu kosowskich Serbów, otwarcie oznajmił: „Nikt nie śmie was bić!". Słowa te przeszły już do historii, stając się symbolem odradzającego się serbskiego nacjonalizmu. Milošević, który w 1989 r. został wybrany na urząd prezydenta Serbii, umiejętnie podsycał rzeczywiste obawy ludności serbskiej, wykorzystując je do budowy własnego poparcia politycznego ${ }^{9}$.

W przeciwieństwie do prezydenta Chorwacji Franjo Tuđmana, serbski przywódca nigdy nie był prawdziwym nacjonalista, lecz klasycznym partyjnym aparatczykiem, zdolnym do cynicznego wykorzystania nierozwiązanych kwestii narodowościowych dla budowy własnej pozycji politycznej. Swoistym paradoksem historii pozostaje, iż to właśnie S. Milošević postrzegany był przez Serbów, w tym także - co niezwykle istotne - przez część środowisk naukowych i serbskiej inteligencji, jako osoba, która mogła zapobiec dalszemu osłabianiu statusu Serbów w całej Jugosławii. Opublikowane w prasie we wrześniu 1986 r. Memorandum uznanej Serbskiej Akademii Nauk i Sztuk (SANU) - jak stwierdza Ana Uzelac - „stało się fundamentem późniejszej polityki nacjonalistycznej”10. Dokument ten wskazywał, że stworzona przez Josipa Broz-Titę struktura SFRJ

\footnotetext{
${ }^{7}$ W. Walkiewicz, dz. cyt., s. 227-244.

8 M. Libal, Ethnic Conflict in the Balkans and in the Caucasus: Some General Considerations, „Southeast European and Black Sea Studies” 2002, vol. 2, no. 2, s. 1-4.

${ }^{9}$ S. Nowak, Kosowo - mit $i$ historia $w$ konflikcie serbsko-albańskim, [w:] Przemiany w świadomości i kulturze duchowej narodów Jugosławii po 1991 roku, Kraków 1999, s. 99; N. Popov, Serbski dramat. Od faszystowskiego populizmu do Miloševicia, Warszawa 1994, s. 51 i n.; S. Miloszewić, Czas rozstrzygnięć, Warszawa 1990, s. 137; R. Tomas, Srbija pod Miloševićem. Politika devedesetih, Beograd 2002, s. 63-70.

${ }^{10}$ A. Uzelac, Slobodan Miloszević, „Gazeta Wyborcza”, 11 VIII 1995, „Magazyn” nr 32,
} s. 10. 
jest nieefektywna i opiera się na celowym osłabieniu i dyskryminacji największej z republik, tj. Serbii, zagrożonej ze strony koalicji antyserbskiej, której głównymi członkami pozostaja Słowenia i Chorwacja ${ }^{11}$. Zawierał on także stwierdzenia o postępującej dezintegracji społeczności serbskiej w Jugosławii, zagrożonej z powodu postępujacej dyskryminacji i asymilacji zarówno w ramach pozostałych republik, jak i w samej Serbii, tj. w autonomicznym Kosowie i Wojwodinie ${ }^{12}$. Jak wskazuje Lora Sikor, Memorandum stanowiło „katalizator, który wyniósł Miloševicia do władzy: stanowiło ono gotowy ideowy podręcznik na rzecz budowy Wielkiej Serbii"13. W tym kontekście obwinianie tylko osoby Miloševicia za wszelkie zło związane z wydarzeniami na Bałkanach jest nie tylko nadmiernie uproszczone, ale i historycznie nieuzasadnione.

Zapewne zdajac sobie sprawe, iż prawdziwa demokratyzacja systemu doprowadzi do odsunięcia od władzy starej komunistycznej nomenklatury partyjnej, S. Milošević sprytnie „zastapił” demokratyzację i modernizację systemu politycznego problemem sporów etnicznych, tworząc - jak stwierdza Adam LeBor wybuchową hybrydę „komunistycznej metodologii i nacjonalistycznej ideologii”" Zdaniem Slavenki Drakulić, prezydent Serbii „stał się nacjonalista, ponieważ był to prosty sposób na pozostanie przy władzy"15. Milošević zapewne doskonale rozumiał „ducha epoki” i zdawał sobie sprawę z faktu, iż - jak ironicznie pisze A. Uzelac - „narodowi, który czuje się zagrożony, nie są potrzebne gospodarka rynkowa, zdrowa ekonomia i swobody polityczne. Zagrożonemu narodowi potrzebny jest Wódz"16. Jeśli zatem rzeczywista demokratyzacja systemu politycznego wydawałaby się najbardziej „cywilizowanym” sposobem „rozwodu” między narodami Jugosławii (stosowny wydaje się w tym kontekście przykład Czechosłowacji), została ona w oczywisty sposób odrzucona przez prezydenta Serbii, a więc największej zarówno pod względem demograficznym, jak i terytorialnym spośród byłych republik SFRJ17.

${ }^{11}$ L. Sikor, Izneverena zaveštanja: jugoslovenski intelektualci i put ka ratu, „Beogradski Krug" 1996, br. 3-4/ 1997, br. 1-2, s. 658-659.

${ }^{12}$ O. Milosavljević, The Abuse of the Authority of Science, [w:] The Road to War in Serbia. Trauma and Catharsis, ed. N. Popov, Budapest 2000, s. 276-284.

${ }^{13}$ L. Sikor, $d z$. cyt., s. 662-663.

${ }^{14}$ A. LeBor, Milosevic. A Biography, London 2003, s. 130-131, 154-155.

${ }^{15}$ S. Drakulić, Oni nie skrzywdziliby nawet muchy. Zbrodniarze wojenni przed Trybunałem $w$ Hadze. Warszawa 2006, s. 80.

${ }^{16}$ A. Uzelac, Slobodan Miloszević..., s. 10.

17 Dostrzegając ten problem w kontekście całego regionu Bałkanów po zakończeniu „zimnej wojny”, Remzi Lani i Frrok Cupi pisza o bałkańskich demokraturach i wskazuja, że „w większości państw regionu przejście od dyktatury do demokracji rozdzielone zostało okresem przejściowym - Nowym Autorytaryzmem. Precyzyjniejsze bedzie jednak stwierdzenie, że w pierwszym okresie przemian więsszość społeczeństw bałkańskich nie przeszła od rządów dyktatorskich do demokracji, ale od totalitarnych reżimów komunistycznych do postkomunistycznych reżimów autorytarnych". Zob. R. Lani, F. Cupi, The Difficult Road to 
Wprowadzając w dniu 28 marca 1989 r. poprawki do konstytucji Serbii, które w poważnym stopniu ograniczyły autonomiczny status Kosowa i Wojwodiny, S. Milošević dokonał centralizacji władzy na poziomie Republiki Serbii, powiązanej z marginalizacja praw mniejszości etnicznych, tj. Albańczyków i Węgrów. Paradoksem pozostaje, iż - jak stwierdza L. Sikor - zamieszkujący we wszystkich republikach Serbowie potrzebowali raczej „słabej” Serbii w ramach Jugosławii ${ }^{18}$. Tymczasem dążący do wzmocnienia władzy w Serbii kosztem autonomii Kosowa i Wojwodiny oraz deklarujący konieczność centralizacji władzy na szczeblu federalnym Milošević faktycznie osłabiał Jugosławię ${ }^{19}$.

Wskazane powyżej działania władz Serbii stworzyły dogodny precedens, który wkrótce powtórzyły władze Republiki Chorwacji. Nowa chorwacka konstytucja, przyjęta w dniu 22 grudnia 1990 r., stała się powodem do niepokojów żyjącej tam mniejszości serbskiej, z powodu pozbawienia Serbów dotychczasowego statusu narodu konstytucyjnego i obaw dotyczących ewentualnego wystapienia Chorwacji z SFRJ20. Poczucie zagrożenia chorwackich Serbów wzmacniała pamięć o krwawych wydarzeniach z okresu II wojny światowej oraz kontrowersyjna „polityka historyczna” F. Tuđmana, który - jak stwierdza Adam Koseski „był „owładnięty ideą budowy Wielkiej Chorwacji” i „rehabilitował przeszłość państwa chorwackiego, nacjonalistycznego, marionetkowego tworu, powołanego do życia dzięki przyzwoleniu hitlerowskich Niemiec"21.

Czy prezydent Serbii rzeczywiście popierał kontynuację federacji jugosłowiańskej? Mimo jednoznaczności niektórych ocen wydaje się, iż w początkowym okresie S. Milošević dążył do centralizacji Jugosławii, co w otwarty sposób prowadziło do konfliktu z władzami Słowenii i Chorwacji, opowiadajacymi się za dalszą decentralizacją federalnego systemu. Analizując szereg faktów i sprzecznych deklaracji oraz często sekretny modus operandi Miloševicia trudno o jednoznaczne wnioski, wydaje się jednak, iż w którymś momencie będący politycznym realista prezydent Serbii po prostu zdał sobie sprawę z nieuchronności rozpadu federacji. Świadomy faktu, iż kontynuacja federacji jugosłowiańskiej w dotychczasowym kształcie jest politycznie martwa idea, Milošević nie tylko zrezygnował z jej realizacji, ale dodatkowo rozpoczął przygotowania na rzecz demontażu federacji ${ }^{22}$.

the Independent Media: Is the Post-Communist Transition Over?, „Southeast European and Black Sea Studies" 2002, vol. 2, no. 1, s. 75 .

18 L. Sikor, $d z$, cyt., s. 658-659.

19 Tamże.

${ }^{20}$ N. Caspersen, The Thorny Issue of Ethnic Autonomy in Croatia: Serb Leaders and Proposals for Autonomy, ,Journal on Ethnopolitics and Minority Issues in Europe” 2003, no. 3, s. 4; K. Krysieniel, System polityczny Republiki Chorwacji, Poznań-Chorzów 2007, s. 70-72.

${ }^{21}$ A. Koseski, W batkańskim tyglu, Pułtusk 2002, s. 98-99; M. Dyras, Re-inkarnacje narodu. Chorwackie narracje tożsamościowe w latach dziewięćdziesiatych XX wieku, Kraków 2009, s. 33-37.

22 A. LeBor, $d z$. cyt., s. 139-140. 
Z pewnością prezydent Serbii nie był zainteresowany zatrzymaniem Słowenii w składzie SFRJ i faktycznie zgodził się na jej wystapienie. W dniu 23 stycznia 1991 r., po spotkaniu prezydentów Republiki Serbii S. Miloševicia i Republiki Słowenii Milana Kučana w Belgradzie, został wydany wspólny komunikat, który wskazywał, że Serbia szanuje „prawo narodu słoweńskiego i Republiki Słowenii do wyboru własnej drogi i podjęcia decyzji w kwestii formuły przyszłych zwiąków z innymi jugosłowiańskimi narodami i republikami”, zaś Słowenia „szanuje pragnienie narodu serbskiego do życia $\mathrm{w}$ granicach jednego państwa i stoi na stanowisku, że przyszły rząd Jugosławii powinien w stosowny sposób odnieść się do powyższego żądania" ${ }^{23}$. Słuszne wydaje się zatem stwierdzenie, że dążący do niepodległości Słowenii M. Kučan i akceptujacy ten fakt S. Milošević posiadali podobne cele polityczne - żaden $\mathrm{z}$ nich nie pragną przetrwania Jugosławii $\mathrm{w}$ dotychczasowych granicach terytorialnych i kształcie systemowym ${ }^{24}$.

Godzac się na wystapienie Słowenii, prezydent Serbii faktycznie wykazał się politycznym realizmem. Jednolita pod względem narodowościowym Słowenia nie stanowiła obszaru historycznego osadnictwa ludności serbskiej, nie posiadała również wspólnej granicy z Serbią i było oczywiste, że z perspektywy historycznej środkowoeuropejskiej Słowenii „blizej” jest do Wiednia niż do Belgradu ${ }^{25}$. Co więcej, Milošević zapewne spodziewał się, że secesja Słowenii stworzy korzystny precedens prymatu zasady samostanowienia narodów nad istniejącymi granicami republik, otwierajacy dyskusję nt. rewizji granic na obszarze SFRJ ${ }^{26}$. Powyższą interpretację potwierdza fakt, iz po wystapieniu Słowenii i Chorwacji z federacji jugosłowiańskiej w dniu 25 czerwca 1991 r. kontrolowane politycznie przez S. Miloševicia Prezydium SFRJ nie podjęło decyzji o rozpoczęciu zmasowanej operacji wojskowej Jugosłowiańskiej Armii Ludowej (JNA) w celu „zatrzymania” Słowenii, której słabo uzbrojone słoweńskie oddziały obrony terytorialnej z pewnością by nie przetrwały ${ }^{27}$. Wiele wskazuje zatem, że mimo oficjalnych i rutynowych deklaracji sprzeciwiajacych się wystapieniu Słowenii, prezydent Serbii faktycznie uznał ten fakt za wydarzenie korzystne, tworzace nadające się do wykorzystania precedensy: secesji i zmiany dotychczasowych granic oraz wykorzystania JNA formalnie przeciw „separatystom”, faktycznie zaś w celu obrony interesów społeczności serbskiej żyjacej poza granicami Republiki Serbii ${ }^{28}$. Wojna w Słowenii, która przeszła do historii jako tzw. wojna dziesięciodniowa,

23 Tamże, s. 135

${ }^{24}$ Tamize, s. $132-138$

25 Tamże; J.J. Wiatr, Stowenia: przykład udanej transformacji, „Zeszyty Naukowe Instytutu Badań Społecznych i Miedzynarodowych Fundacji im. Kazimierza Kelles-Krauza” 1998, nr 2, s. 7-20; Facts about Slovenia 2006, Government of the Republic of Slovenia, Public Relations and Media Office, Ljubljana 2006, s. 29-33.

${ }^{26}$ A. LeBor, dz. cyt., s. 136.

27 Tamże, s. 137-138.

${ }_{28}$ Tamize. 
zakończyła się tak szybko, iż wiele wskazuje na to, że zakończyła się ona zgodnie z planem ${ }^{29}$. Jaki był zatem ów plan?

Jakkolwiek S. Milošević nigdy publicznie nie odwołał się do koncepcji „Wielkiej Serbii”, a nawet odcinał się od tego rodzaju interpretacji, wiele wskazuje jednak, iż był on realizatorem tej właśnie polityki ${ }^{30}$.

Koncepcja „Wielkiej Serbii” pojawiła się już w XIX w. i zakładała zjednoczenie w granicach jednego państwa narodowego wszystkich Serbów, rozrzuconych po Półwyspie Bałkańskim w wyniku niekorzystnych procesów historycznych (wojny, migracje i okupacja turecka) ${ }^{31}$. Oficjalnie niepodległa od 1878 r. Serbia była państwem ograniczonym terytorialnie i poza jej granicami pozostawały m.in. Kosowo, Macedonia oraz Bośnia, a więc terytoria uznawane za historycznie serbskie, a dodatkowo zamieszkałe przez ludność serbska, wśród której - jak pisze Mieczysław Tanty - „dominowało [...] dążenie do jedności z państwem serbskim, które uważano za ośrodek konsolidowania wszystkich Serbów"32.

$\mathrm{Na}$ realizację koncepcji zjednoczeniowej w XIX w. nie pozwoliła zarówno obiektywna słabość Serbii, jak i polityka wielkich mocarstw. Postanowienia kongresu berlińskiego z 1878 r., na mocy których Turcja przekazywała administrację Bośni i Hercegowiny Austro-Węgrom, stanowiły wykluczenie tego terytorium ze strefy wpływów Serbii, co, jak stwierdza Stevan Pavlowitch: „zniweczyło marzenia o zjednoczeniu wszystkich Serbów w niepodległym państwie”"33. Nie może zatem dziwić, że aneksja Bośni i Hercegowiny przez Austro-Węgry w 1908 r. spotkała się z ostrym sprzeciwem zarówno mieszkającej w Bośni ludności serbskiej, jak i Królestwa Serbii, które czynnie wspierało zjednoczeniowe dążenia Słowian Południowych ${ }^{34}$. Gavrilo Princip, człowiek, który 28 czerwca 1914 r. dokonal zabójstwa arcyksięcia Franciszka Ferdynanda w Sarajewie, był Serbem pochodzacym z Bośni i Hercegowiny i członkiem tajnej organizacji „Młoda Bośnia”, dążącej do zjednoczenia narodów południowosłowiańskich, zaś sam zamach został przeprowadzony przy wsparciu kontrwywiadu wojskowego Serbii. Przez kolejne dekady ten młody serbski nacjonalista był oficjalnym symbolem jugosłowiańskiego patriotyzmu ${ }^{35}$.

${ }^{29}$ Tamże; N. Thomas, K. Mikulan, The Yugoslav Wars (1). Slovenia \& Croatia 1991-95, Oxford 2006, s. 15-20.

30 Jak pisze A. Uzelac: „nie pojawiały się [...] w jego ustach słowa «Wielka Serbia», nigdy też nie wypowiadał frazy o "wszystkich Serbach w jednym państwie». Znowu sie potwierdziła jego polityczna dalekowzroczność: jego ręce formalnie pozostały zupełnie czyste" - zob.: A. Uzelac, Slobodan Miloszević..., s. 10.

31 J. Batt, The Question of Serbia, Paris 2005, s. 13.

32 M. Tanty, Batkany w XX wieku. Dzieje polityczne, Warszawa 2003, s. 106-107.

${ }^{33}$ S.K. Pavlowitch, Historia Batkanów (1804-1945), Warszawa 2009, s. 140-141.

${ }_{34}$ J. Skowronek, M. Tanty, T. Wasilewski, Stowianie południowi $i$ zachodni VI-XX wiek, Warszawa 2005, s. 498-499.

${ }_{35}$ Tamże. 
Koniec I wojny światowej doprowadził do zastapienia koncepcji „Wielkiej Serbii” alternatywną ideą jugosłowiańska, która pozwoliła na urzeczywistnienie oczekiwanego zjednoczenia wszystkich Serbów w jednym państwie. Nie było to wprawdzie państwo narodowe, lecz utworzone w dniu 1 grudnia 1918 r. wielonarodowe Królestwo Serbów, Chorwatów i Słoweńców ${ }^{36}$. Mimo wyraźnych tendencji separatystycznych i krwawych bratobójczych walk z okresu II wojny światowej, idea wspólnego państwa, do której odwoływała się zwycięska siła polityczna, tj. jugosłowiańska partia komunistyczna J. Broz-Tity, została odnowiona powołaniem do życia w dniu 29 listopada 1945 r. Federacyjnej Ludowej Republiki Jugosławii i przetrwała do końca „zimnej wojny”37. Jak w tym kontekście zauważa Vanni Cappelli, w XX w. Serbowie dwukrotnie i dobrowolnie zrezygnowali z budowy „Wielkiej Serbii”, popierając koncepcję wielonarodowej Jugosławii ${ }^{38}$.

Funkcjonowanie zarówno „pierwszej”, jak i „drugiej” Jugosławii pokazało jednak, że ani przedwojenny model autorytarnej centralizacji, ani częściowa decentralizacja systemu $\mathrm{z}$ lat 70 . XX w. nie doprowadziły do ustanowienia wiarygodnego wspólnego bytu państwowego, cieszacego się powszechną akceptacją większości obywateli. Oficjalna ideologia „braterstwa i jedności” w oczywisty sposób nie zastapiła tożsamości etnicznej mieszkańców Jugosławii, tym bardziej, że ciagle żywa pozostawała pamięć o wydarzeniach nieodległej przeszłości, tj. okresie krwawych bratobójczych walk i zbrodni z czasów II wojny światowej. W przeciwieństwie do Czechów i Słowaków stosunki między narodami SFRJ cechował raczej wzajemny brak zaufania i poczucie zagrożenia niż pozytywna obojętnośćc ${ }^{39}$.

Kryzys ekonomiczny dekady lat 80 . XX w. i demokratyzacja systemu politycznego na przełomie lat 80 . i 90 . przyniosły ze soba poważny wzrost tłumionych wcześniej postaw antykomunistycznych, separatystycznych i nacjonalistycznych, które stanowiły poważne zagrożenie dla kontynuacji wspólnego państwa ${ }^{40}$.

Jeśli jednak pozostałe narody i narodowości Jugosławii postrzegały możliwość rozpadu jako naturalny proces demokratyzacji systemu politycznego, dajacy im możliwość utworzenia własnych państw narodowych, zamieszkujacca SFRJ ludność serbska postrzegała ewentualną dezintegrację kraju z wyraźną obawą. Serbowie stanowili najliczniejszy naród federacji i zamieszkiwali na terenie wszystkich republik Jugosławii. Poza sama Serbia najliczniejsze skupiska ludności serbskiej znajdowały się na terytorium Bośni i Hercegowiny i Chorwacji, gdzie Serbowie stanowili odpowiednio $33 \%$ i $12 \%$ ludności ${ }^{41}$. Nie może zatem

36 J. Batt, dz. cyt., s. 16.

${ }_{37}$ Tamże.

38 V. Cappelli, The Bosnian Question and the Great Powers, „Mediterranean Quarterly" 1997, vol. 8, no. 1, s. 104.

39 J. Batt, $d z$. cyt., s. 14-17.

${ }^{40}$ Tamże, s. 15.

${ }^{41}$ Tamże, s. 15-16. 
dziwić, iż secesjonistyczne dążenia Słowenii i Chorwacji budziły głęboki niepokój Serbów, związany z możliwością kolejnego już „podziału” narodu serbskiego, dokonanego przez wytyczenie nowych granic państwowych na gruzach SFRJ. W efekcie Serbowie popierali centralizację władzy federalnej i kontynuację Jugosławii, stając się w ten sposób przeciwnikiem niepodległościowych aspiracji pozostałych narodów Jugosławii ${ }^{42}$. W opinii L. Sikor, ze wszystkich narodów jugosłowiańskich to właśnie Serbowie najbardziej potrzebowali zjednoczonej Jugosławii ${ }^{43}$. Warto $\mathrm{w}$ tym miejscu przytoczyć opinię V. Cappellego, który stwierdza, że na początku lat 90. XX w. Chorwaci i Muzułmanie chcieli wystapić ze struktury federalnej „zabierając ze sobą o wiele więcej terytoriów, niż mogliby uzyskać, gdyby rozpad nastapił wzdłuż granic etnicznych, a nie republikańskich" ${ }^{44}$.

Im bardziej jednak było jasne, iż ogarnięta nieustannym kryzysem wewnętrznym i coraz bardziej dezintegrująca się wskutek tendencji odśrodkowych Słowenii i Chorwacji Jugosławia nie przetrwa w dotychczasowym kształcie „jesieni narodów”, żyjąca poza terytorium Serbii ludność serbska sama stała się podmiotem podsycanych przez władze Serbii działań separatystycznych.

Kontrolujący scenę polityczną oraz środki masowego przekazu w Serbii prezydent Milošević nie tylko umiejętnie wykorzystywał możliwość medialnej propagandy i wzmacniał rzeczywiste obawy Serbów, ale także czynnie wspierał perspektywę siłowego rozwiązania problemów serbskich mniejszości. Mieszkający w Chorwacji oraz w Bośni i Hercegowinie Serbowie zostali w nielegalny sposób zaopatrzeni w broń dostarczoną im przez Służbę Bezpieczeństwa Państwowego (SDB) Republiki Serbii ${ }^{45}$. Zamiast dążyć do łagodzenia i pokojowego rozstrzygnięcia istniejących obiektywnie problemów narodowościowych S. Milošević świadomie podsycał konflikty etniczne, godząc się na możliwość siłowego ich rozwiązania i zastapienia istniejącej SFRJ nowym bytem państwowym, w skład którego weszłyby terytoria zamieszkiwane przez ludność serbską. Ta właśnie „Wielka Serbia”, a więc własne państwo narodowe, o którym od wieków śnili serbscy nacjonaliści, miała swym zasięgiem objąć większość ziem Jugosławii zamieszkanych przez ludność serbska, tj. Serbię właściwa, Macedonię, Bośnię i Hercegowinę, Czarnogórę oraz część Chorwacji ${ }^{46}$.

Jakkolwiek zaangażowanie prezydenta Serbii w przygotowanie siłowego „demontażu” Jugosławii zwykle nie jest kwestionowane (co nie umniejsza "grzechów” pozostałych decydentów, na czele z przywódcą Chorwacji F. Tuđmanem), każdy, nawet najzagorzalszy przeciwnik S. Miloševicia powinien dostrzec,

42 Tamie.

${ }^{43}$ L. Sikor, $d z$. cyt., s. 659

44 V. Cappelli, dz. cyt., s. 104.

45 A. LeBor, $d z$. cyt., s. 141-144.

46 Tamize. 
iż akceptując prawo narodów do samostanowienia, pozwalające Słoweńcom i Chorwatom na wystapienie $\mathrm{z}$ federacji i budowę własnych niepodległych państw narodowych, nie można tego samego prawa odmówić także Serbom. Kiedy więc na początku lat 90. XX w. stare ograniczenia i zasady powoli odchodziły w przeszłość, także Serbowie wystapili z żądaniem ustanowienia własnego państwa narodowego ${ }^{47}$. Nie zmienia to oczywiście faktu, iż sposób demontażu federacji, a zwłaszcza problem ewentualnej korekty istniejacych granic wewnętrznych, mógł być i z pewnościa powinien zostać przeprowadzony w inny sposób, czego przykładem pozostaje pokojowy rozpad Czechosłowacji.

\section{Wojna w Bośni i Hercegowinie (1992-1995)}

Kiedy w czerwcu $1991 \mathrm{r}$. JNA podjęła działania zbrojne przeciw występujacym z federacji Słowenii i Chorwacji, będąca dalej częścią SFRJ Bośnia i Hercegowina znalazła się w bardzo niekorzystnym położeniu. W przeciwieństwie do Słowenii i Chorwacji struktura etniczna Bośni była bardziej zrównoważona i tworzyły ją trzy główne narody: Muzułmanie (43,7\%), Serbowie (31,3\%) i Chorwaci (17,3\%), które nie zamieszkiwały zwartych etnicznie terytoriów. Na przestrzeni kilkudziesięciu lat struktura etniczna republiki uległa istotnej zmianie - stanowiący w 1961 r. najliczniejszą grupę narodowościową w Bośni Serbowie $(42,9 \%)$ do 1991 r. stali się drugim liczebnie narodem (po Muzułmanach, stanowiących w 1961 r. 25,7\%). Bośnia i Hercegowina stanowiła więc „małą Jugosławię” lub tė̇ „republikę bez narodu” i można było przypuszczać, iż wszelkie radykalne działania dotyczące jej statusu wywołają opór części mieszkańców ${ }^{48}$.

W sytuacji rzeczywistego rozpadu SFRJ przed Bośnią i Hercegowiną pojawiła się zatem alternatywa pozostania w składzie zdominowanej przez Serbów Jugosławii (,Serbosławii”) lub ogłoszenie niepodległości, które musiało w oczywisty sposób doprowadzić do wojny, z uwagi na spodziewany sprzeciw bośniackich Serbów, na czele których stał zaufany współpracownik S. Miloševicia, ekscentryczny nacjonalista Radovan Karadžić, przewodniczacy utworzonej w lipcu 1990 r. Serbskiej Partii Demokratycznej (SDS) ${ }^{49}$. SDS zdecydowanie opowiadała się za unifikacją wszystkich Serbów w granicach jednego państwa, tj. Jugosławii,

${ }^{47}$ I.W. Zartman, Toward the Resolution of International Conflicts, [w:] Peacemaking in International Conflict. Methods \& Techniques, eds. I.W. Zartman, J.L. Rasmussen, Washington 1997, s. 5.

${ }^{48}$ L. Hamourtziadou, The Bosniaks: from Nation to Threat, „Journal of Southern Europe and the Balkans" 2002, vol. 4, no. 2, s. 149-155.

${ }^{49}$ A. LeBor, dz. cyt., s. 139, 171-181. 
i odrzucała wszelkie dyskusje nt. ewentualnej secesji i niepodległości Bośni i Hercegowiny. Partia bośniackich Serbów nie posiadała jednak wystarczającego potencjału politycznego, który pozwoliłby jej na utrzymanie Bośni w składzie Jugosławii na drodze pokojowego dialogu. Alternatywnym rozwiązaniem - akceptowanym zarówno przez prezydenta Serbii, jak i liderów bośniackich Serbów stało się zatem rozstrzygnięcie siłowe $\mathrm{e}^{50}$.

Można przypuszczać, iż S. Milošević planował pozostawienie całej Bośni w składzie Jugosławii, a ściślej tego, co miało z niej pozostać po secesji Słowenii i zapewne akceptowanej niepodległości części Chorwacji. Faktycznie początkowo prezydent Serbii powstrzymywał się od wrogich deklaracji wobec bośniackich Muzułmanów. Tym niemniej w dniu 25 marca 1991 r. doszło do znamiennego spotkania S. Miloševicia i F. Tuđmana w Karađorđevie. Jest niemal pewne, że to właśnie wówczas obaj przywódcy podjęli decyzję odnośnie do dalszych losów Bośni i Hercegowiny i uzgodnili, iż republika ta jest tworem sztucznym i powinna zostać podzielona między posiadające „uzasadnione” roszczenia terytorialne Serbię i Chorwację ${ }^{51}$.

Powyższa interpretację potwierdza ciche, ale jednocześnie świadome zaangażowanie S. Miloševicia w planowanie i przygotowywanie siłowego rozstrzygnięcia napięć etnicznych w Bośni i Hercegowinie. W tym celu - przy poparciu i pełnej wiedzy prezydenta Serbii - SDB, którą kierował Jovica Stanišić, w niejawny sposób zaopatrywała serbskich cywilów w Bośni w broń oraz wspierała tworzenie i szkolenie serbskich oddziałów paramilitarnych, zapewniając im także konieczne wsparcie finansowe i logistyczne ${ }^{52}$. Oddziały te wzięły później udział w walkach m.in. na terytorium Bośni i Hercegowiny, gdzie dopuściły się wszelkich możliwych aktów zbrodni i przemocy. Z pewnością stanowiły one wprawdzie „nieformalną”, ale niezwykle skuteczną siłę wojskową serbskiego prezydenta. Milošević umiejętnie wykorzystywał także lojalne wobec niego media publiczne w Serbii, które stały się narzędziem wrogiej propagandy wobec Chorwatów i bośniackich Muzułmanów, mającej na celu wywołanie poczucia zagrożenia wśród Serbów żyjących na terytorium całej Jugosławii oraz intensyfikację konfliktów na tle etnicznym ${ }^{53}$.

Prezydent Serbii zaangażował się także w organizację „politycznego przewrotu" w Bośni i Hercegowinie. Zwłaszcza w okresie przed wybuchem konfliktu zbrojnego S. Milošević posiadał istotny wpływ na przywódców bośniackich

${ }^{50}$ Tamże; The International Criminal Tribunal for the Former Yugoslavia (dalej: TICTFY), Case No. IT-02-54-T. The Prosecutor of the Tribunal against Slobodan Milosevic. Amended Indictment, http://www.icty.org/x/cases/slobodan_ milosevic/ind/en/mil-ai040421-e.htm.

${ }_{51} \mathrm{~A}$. LeBor, $d z$. cyt., s. $166-173$.

52 TICTFY, Case No. IT-03-69-PT. The Prosecutor v. Jovica Stanišić and Franko Simatović, http://www/icty.org/x/cases/stanisic_simatovic/ind/staj-in3rd amd080710.pdf.

${ }^{53}$ Tamże; TICTFY, Case No. IT-02-54-T...; S. Drakulić, dz. cyt., s. 152. 
Serbów, którzy byli świadomi swej politycznej i materialnej zależności i pozostawali w istocie wykonawcami decyzji podjętych w Belgradzie. Wykorzystane przez Międzynarodowy Trybunał Karny dla byłej Jugosławii (ICTY) nagrania z podsłuchów rozmów telefonicznych między S. Miloševiciem i R. Karadžiciem, dokonane prawdopodobnie przez służby wywiadowcze Bośni i Hercegowiny w 1991 r. i 1992 r., nie tylko wskazuja na bliskie i zażyłe związki między obu politykami ${ }^{54}$, ale także jednoznacznie dokumentuja, iż sukcesywnie i w pełni świadomie przygotowywali się oni do rozpoczęcia działań zbrojnych w Bośni ${ }^{55}$.

Nagrania pokazują również, że w przygotowania zaangażowano także część dowództwa JNA. Oficjalnie była to $\mathrm{w}$ dalszym ciagu armia federacyjna i wielonarodowościowa, lecz na szczeblu dowódczym dominowali w niej Serbowie i Czarnogórcy. JNA nieformalnie kontrolował S. Milošević za pomocą powiązanych z nim polityków na szczeblu Prezydium SFRJ, które sprawowało oficjalną i kolektywną władzę nad armią oraz poprzez sieć zwolenników w korpusie generalskim i oficerskim ${ }^{56}$. W świetle powyższych okoliczności przywódcy bośniackich Serbów mogli być zatem pewni, że w wypadku wybuchu działań wojennych w republice otrzymaja pomoc wojskowa ze strony Republiki Serbii i armii federalnej ${ }^{57}$. Stało się to tym bardziej oczywiste, kiedy okazało się, że oficjalnie bezstronna JNA wsparła militarnie działania Serbów w Chorwacji. O prawdopodobnej woli powtórzenia takiego scenariusza w Bośni i Hercegowinie świadczył fakt, iż na jesieni 1991 r. władze SFRJ zaczęły wycofywać JNA z Chorwacji, zaś część jej oddziałów została rozmieszczona w Bośni, w tym także na obszarach, gdzie nie było wcześniej garnizonów czy innej infrastruktury JNA ${ }^{58}$.

Pierwsze działania podjęte przez bośniackich Serbów w celu konsolidacji terenów serbskich w Bośni i Hercegowinie pojawiły się już w kwietniu $1991 \mathrm{r}$. w postaci stowarzyszeń gmin zamieszkanych przez ludność serbską ${ }^{59}$. W okresie od września do listopada 1991 r. bośniaccy Serbowie ogłosili powstanie kilku Serbskich Regionów Autonomicznych, będących samozwańczymi (i w zamierzeniu autonomicznymi) serbskimi jednostkami administracyjnymi w ramach Bośni i Hercegowiny ${ }^{60}$.

${ }^{54} \mathrm{Z}$ odtworzonego zapisu wynika, że R. Karadžić i S. Milošević niejednokrotnie rozmawiali telefonicznie do trzech razy dziennie, zaś przywódca bośniackich Serbów jeździł do Belgradu na konsultacje praktycznie co tydzień.

${ }_{55}$ A. Uzelac, Milosevic Wire Tap Revelations. Telephone Intercepts Appear to Expose Milosevic Role in Croatian and Bosnian Conflicts, Institute for War \& Peace Reporting, http://iwpr.net/report-news/milosevic-wire-tap-revelations.

${ }_{56}$ Tamż; . Thomas, K. Mikulan, The Yugoslav Wars (1)..., s. 11.

${ }^{57}$ A. Uzelac, Milosevic Wire Tap Revelations...

58 TICTFY, Case No. IT-02-54-T...

${ }_{59}$ Tamże.

${ }^{60}$ Tamże. 
Do zaostrzenia sytuacji politycznej doszło, kiedy w dniu 15 października 1991 r. Zgromadzenie Bośni i Hercegowiny dyskutowało kwestię suwerenności republiki. W czasie debaty parlamentarnej R. Karadžić w otwarty sposób ostrzegł Muzułmanów, że sprowadzą na siebie „piekło”, jeśli podejmą decyzję o ogłoszeniu niepodległości Bośni i Hercegowiny, ponieważ władze republiki nie będą w stanie obronić bośniackich Muzułmanów w sytuacji, kiedy dojdzie do niechybnej wojny ${ }^{61}$. Mimo sprzeciwu serbskich deputowanych, którzy przed głosowaniem w proteście opuścili salę obrad, idąc za przykładem Słowenii i Chorwacji Zgromadzenie głosami Muzułmanów i Chorwatów przyjęło deklarację suwerenności Bośni ${ }^{62}$. Jeszcze tego samego dnia serbscy posłowie podjęli decyzję o powołaniu „własnego” parlamentu. Powstałe w dniu 24 października 1991 r. Zgromadzenie Narodu Serbskiego Bośni i Hercegowiny podjęło niezwłocznie decyzję o przeprowadzeniu wśród Serbów referendum nt. tego, czy Bośnia powinna pozostać w Jugosławii, czy też stać się niepodległym państwem ${ }^{63}$.

Łatwe do przewidzenia wyniki referendum z 9-10 listopada 1991 r. pokazały, iż zdecydowana większość Serbów z Bośni i Hercegowiny pragnie pozostać w Jugosławii. W dniu 21 listopada 1991 r. Zgromadzenie Narodu Serbskiego Bośni i Hercegowiny ogłosiło, iż gminy, w których większość głosujaccych opowiedziała się za pozostaniem w składzie federacji, stanowią część terytorium Jugosławii. W dniu 11 grudnia 1991 r. Zgromadzenie Narodu Serbskiego Bośni i Hercegowiny złożyło oficjalna prośbę do JNA o ochronę wszelkimi możliwymi środkami - jako stanowiących „integralną część państwa Jugosławia” - tych terytoriów Bośni, których mieszkańcy opowiedzieli się w referendum za pozostaniem w ramach Jugosławii. W dniu 9 stycznia 1992 r. Zgromadzenie bośniackich Serbów proklamowało powstanie Serbskiej Republiki Bośni i Hercegowiny, deklarujac, iż wchodzi ona w skład federalnej Jugosławii64.

Od 29 lutego do 1 marca 1992 r. w Bośni i Hercegowinie odbyło się zorganizowane przez władze republiki referendum w kwestii niepodległości. Wyniki wskazywały, że przy frekwencji wynoszącej 63\% uprawnionych do głosowania zdecydowana większość, tj. 99\% głosujących (głównie Muzułmanów i Chorwatów), opowiedziała się za całkowitą niepodległością Bośni i Hercegowiny. Na wniosek SDS większość bośniackich Serbów zbojkotowała udział w referendum ${ }^{65}$.

${ }^{61}$ A.J. Kuperman, The Moral Hazard of Humanitarian Intervention: Lessons from the Balkans, ,International Studies Quarterly” 2008, vol. 52, no. 1, s. 58-59.

62 TICTFY, Case No. IT-99-36-T. Prosecutor v. Radoslav Brdanin, Judgement, http://www.icty.org/x/cases/brdanin/tjug/en/brd-tj040901e.pdf.

${ }_{63}$ TICTFY, Case No. IT-02-54-T...

${ }^{64}$ Tamże.

${ }^{65}$ Tamże; M. Kasapović, Bosnia and Herzegovina: Consociational or Liberal Democracy?, „Politička misao” 2005, br. 5, s. 10; Final Report of the United Nations Commission of Experts Established Pursuant to Security Council Resolution 780 (1992), Annex IV, The Policy of Ethnic Cleansing, http://www/law.depaul.edu/centers_institutes/ihrli/downloads/ Annex_IV.pdf. 
Jakkolwiek wynik referendum mógł być postrzegany jako casus belli, faktycznie jednak bośniaccy Serbowie byli już od dawna do wojny przygotowani. Od marca 1992 r. oddziały Obrony Terytorialnej (TO) bośniackich Serbów, wspierane przez różne serbskie formacje paramilitarne oraz wojska stacjonującej w republice JNA rozpoczęły przejmowanie pełnej kontroli nad obszarami Bośni i Hercegowiny, uznanymi przez nich za terytoria serbskie. Ich działania polegały na użyciu siły militarnej wobec ludności muzułmańskiej i chorwackiej w celu zmuszenia jej do opuszczenia dotychczasowego miejsca zamieszkania ${ }^{6}$.

„Modelowym” wręcz przykładem powyższej współpracy pozostaje brutalna agresja militarna i zajęcie miasta Zvornik, leżącego nad rzeką Driną na granicy Bośni i Serbii. W dniu 8 kwietnia 1992 r. oddziały TO bośniackich Serbów ${ }^{67}$, przybyłe z Serbii lub innych części dawnej Jugosławii serbskie paramilitarne formacje ochotnicze, tj. Serbski Ruch Czetnicki (Srpski Četnički Pokret), Białe Orły (Beli Orlovi), Serbska Straż Ochotnicza (Srpska Dobrovoljačka Garda) oraz jednostki JNA rozpoczęły skoordynowany ostrzał miasta, które zostało zdobyte do 11 kwietnia ${ }^{68}$.

Zajęcie Zvornika z pewnością nie było przypadkowe. Leżące na granicy republik miasto stanowiło ważny węzeł komunikacyjny na linii BelgradSarajewo i z powodów logistycznych (tj. zapewnienia swobodnego dopływu zaopatrzenia dla oddziałów bośniackich Serbów) jego zajęcie wydawało się konieczne i oczywiste. O planowym i zorganizowanym charakterze ataku świadczy fakt, iż jeszcze przed rozpoczęciem działań część serbskich mieszkańców miasta ostrzegała swoich muzułmańskich przyjaciół i znajomych, wskazując, że z uwagi na własne bezpieczeństwo powinni opuścić Zvornik, zaś w trakcie prowadzonych walk kobiety i dzieci narodowości serbskiej znajdowały się poza miastem. Wydarzenia te pozwalaja przypuszczać, iż serbscy cywile mieli przynajmniej cząstkową wiedzę nt. zbliżającego się ataku. Ultranacjonalista i przywódca serbskich czetników Vojislav Šešelj wskazywał, iż cała operacja została starannie zaplanowana i przygotowana w Belgradzie. W czasie zajmowania miasta oraz po jego zajęciu serbskie oddziały paramilitarne zamordowały kilkadziesiąt osób cywilnych ${ }^{69}$.

Należy wyraźnie podkreślić, iż w ataku na Zvornik uczestniczyli żołnierze oraz sprzęt wojskowy (tj. czołgi i artyleria) armii federalnej. Przynajmniej część

${ }^{66}$ N. Thomas, K. Mikulan, The Yugoslav Wars (2). Bosnia, Kosovo and Macedonia 1992-2001, Oxford 2006, s. 11, 22-29.

$67 \mathrm{~W}$ okresie dwóch-trzech miesiecy poprzedzajacych atak na Zvornik oddziały serbskiej TO przeszły przeszkolenie wojskowe prowadzone przez JNA. Wzięli w nich udział wyłącnie Serbowie - zob. Final Report of the United Nations Commission of Experts...

${ }^{6}$ Tamże; N. Thomas, K. Mikulan, The Yugoslav Wars (1)..., s. 42-44.

${ }^{69}$ Final Report of the United Nations Commission of Experts...; A. LeBor, dz. cyt., s. 191-193; N. Thomas, K. Mikulan, The Yugoslav Wars (1)..., s. 43. 
sił JNA, biorących udział $\mathrm{w}$ ataku, została wcześniej przemieszczona w okolice Zvornika po opuszczeniu garnizonu w miejscowości Jastrebarsko w Chorwacji, skąd została wycofana przez władze SFRJ ${ }^{70}$. Wprawdzie oddziały przed atakiem dokonały usunięcia oznaczeń „JNA” z mundurów i żołnierze posiadali odznaki przedstawiajace flagę Serbii, niemniej jednak pojazdy wojskowe w dalszym ciagu posiadały oznaczenia JNA. Krótko mówiąc, była to ta sama armia, nawet jeśli „oficjalnie" występowała pod flagą Serbii. Dla Muzułmanów ostrzeliwanych pociskami JNA powyższa różnica posiadała charakter czysto akademicki. Dodatkowo warto zauważyć, iż atak na Zvornik przeprowadzono z dwóch kierunków - działaniom zbrojnym prowadzonym na terytorium Bośni i Hercegowiny towarzyszył ostrzał artyleryjski prowadzony przez JNA z miejscowości Mali Zvornik, leżącej za rzeka Driną na terytorium Republiki Serbii ${ }^{11}$. Jak zatem podsumowuje A. LeBor: „Atak na Zvornik stanowi najbardziej oczywisty dowód, iż stanowisko Miloševicia, że Serbia nie jest zaangażowana w wojnę w Bośni, było kłamstwem"72.

W ataku na Zvornik uczestniczyła JNA, podległa formalnie jurysdykcji Prezydium SFRJ (wówczas już w poważnie okrojonym składzie, tj. bez przedstawicieli Chorwacji, Słowenii, Macedonii oraz Bośni i Hercegowiny), zaś nieformalnie prezydentowi Serbii S. Miloševiciowi. Dopiero w dniu 8 maja 1992 r. władze utworzonej 27 kwietnia 1992 r. FRJ, w skład której weszły Serbia i Czarnogóra, podjęły decyzję o przekształceniu JNA w Armię Jugosławii (VJ) i wycofywaniu oddziałów dawnej JNA z terytorium Bośni i Hercegowiny. Do 19 maja $1992 \mathrm{r}$. wycofywanie zostało oficjalnie zakończone. Republikę opuściło jednak tylko 14 tys. żołnierzy, którzy nie pochodzili z Bośni i Hercegowiny, zaś 80 tys. żołnierzy i sprzęt wojskowy pozostawiono w republice na potrzeby powstającej armii bośniackich Serbów. Co więcej, władze Jugosławii skierowały do Bośni urodzonych tam żołnierzy narodowości serbskiej, którzy dotychczas służyli w innych częściach Jugosławii ${ }^{73}$. Te właśnie siły wojskowe, składające się z byłej JNA stanowiły trzon utworzonych w dniu 12 maja 1992 r. i oficjalnie niezależnych od FRJ sił zbrojnych bośniackich Serbów, które od 12 sierpnia 1992 r. funkcjonowały pod oficjalną nazwą Armia Republiki Serbskiej (VRS) ${ }^{74}$. Nowo utworzona VRS przejęła strukturę organizacyjna, wyposażenie (m.in. czołgi i artylerię) oraz umundurowanie dawnej JNA, zaś na jej czele stanął gen. Ratko

${ }^{70}$ Final Report of the United Nations Commission of Experts...

${ }^{71}$ Tamż; A. LeBor, dz. cyt., s. 176-177, 191-192.

${ }^{72}$ A. LeBor, dz. cyt., s. 191.

${ }^{73}$ International Court of Justice, Case Concerning the Application of the Convention on the Prevention and Punishment of the Crime and Genocide (Bosnia and Herzegovina v. Serbia and Montenegro), 26 February 2007, http://www/icj-cij.org/docket/files/91/13685.pdf.

${ }^{74}$ N. Thomas, K. Mikulan, The Yugoslav Wars (1)..., s. 12; N. Thomas, K. Mikulan, The Yugoslav Wars (2)..., s. 12-14, 32. 
Mladić, do niedawna oficer JNA, nacjonalista i aktywny wykonawca polityki S. Miloševicia ${ }^{75}$.

Mimo międzynarodowego embarga zarówno wówczas, jak i w późniejszym okresie wojny, FRJ aktywnie wspierała siły zbrojne bośniackich Serbów, dostarczając VRS wsparcie finansowe i materialne. Według władz Bośni i Hercegowiny ok. 90\% uzbrojenia i innych materiałów niezbędnych VRS do prowadzenia operacji wojskowych pochodziło z FRJ. Dodatkowo, przynajmniej część korpusu oficerskiego VRS (być może ok. 1,8 tys. z ok. 14 tys. oficerów VRS) była bezpośrednio opłacana przez władze FRJ, podlegajac administracyjnie VJ w zakresie wynagrodzenia, awansów i spraw emerytalnych ${ }^{76}$. Międzynarodowy Trybunał Sprawiedliwości (MTS) stwierdził wprawdzie, że w świetle prawa międzynarodowego „ani Republika Serbska, ani VRS nie stanowiły de iure organów FRJ”, stanowisko to nie zmienia jednak faktu, iz podmioty te de facto aktywnie uczestniczyły w realizacji „wspólnego przestępczego przedsięwzięcia” dopuszczając się zbrodni wojennych, za które został oskarżony przed ICTY m.in. S. Milošević, a więc prezydent Republiki Serbii, wchodzącej w skład FRJ, formalnie neutralnej w konflikcie zbrojnym toczącym się w Bośni i Hercegowinie ${ }^{77}$.

W ramach działań militarnych prowadzonych przez serbskie oddziały TO, ochotnicze jednostki paramilitarne, JNA, a potem VRS oraz jednostki SDB Ministerstwa Spraw Wewnętrznych Republiki Serbii, siły te atakowały, a następnie przejmowały kontrolę nad miastami i wsiami w Bośni i Hercegowinie. W czasie zajmowania terytoriów prowadzona była planowa kampania „czystek etnicznych”, polegająca na przymusowych i masowych deportacjach ludności muzułmańskiej i chorwackiej, mieszkańcy nie będący Serbami stawali się ofiarami morderstw, poddawano ich różnego rodzaju aktom gwałtów, przemocy i rabunku, utrudniano udzielanie im pomocy humanitarnej, blokując dostawy żywności i leków, kierowano ich do obozów odosobnienia, gdzie poddawano ich różnym technikom dręczenia i przemocy, a czasami brutalnie mordowano, niszczono także ich nieruchomości oraz zabytki kultury (meczety, kościoły, biblioteki itp.). Celem takiego działania było „wyczyszczenie” obszarów uznanych za serbskie terytorium etniczne. Pozwala to na stwierdzenie, iż „czystki etniczne” nie były skutkiem, ale raczej celem działań wojennych prowadzonych przez Serbów w Bośni i Hercegowinie, mających doprowadzić do stworzenia etnicznie czystej „Wielkiej Serbii"78.

75 N. Thomas, K. Mikulan, The Yugoslav Wars (2)..., s. 12-13.

${ }^{76}$ TICTFY, Case No. IT-02-54-T...; International Court of Justice, Case Concerning the Application...

77 Zob. i por. TICTFY, Case No. IT-02-54-T...; International Court of Justice, Case Concerning the Application...

${ }^{78}$ TICTFY, Case No. IT-02-54-T...; S. Drakulić, dz. cyt., s. 68-69. 
„Protagoniści pokoju”79

Wiele wskazuje zatem, iz stanowisko prezydenta S. Miloševicia, który uporczywie twierdził, że nie sprawuje kontroli nad działaniami bośniackich Serbów, było niezgodne z prawdą. Charakter politycznej i ekonomicznej zależności między przywódcami Serbów z Bośni a decydentami w Belgradzie był de facto oczywisty i większość obserwatorów doskonale rozumiała, że prawdziwym decydentem odnośnie do wydarzeń w Bośni i Hercegowinie pozostawał prezydent Serbii, który oficjalnie wskazywał, że jego kraj nie jest w stanie wojny z żadnym państwem. W efekcie nie tylko bośniaccy Serbowie, ale także wspierająca ich Jugosławia stała się podmiotem międzynarodowych sankcji politycznych i ekonomicznych ${ }^{80}$.

Uznaniu niepodległości Słowenii, Chorwacji oraz Bośni i Hercegowiny przez społeczność międzynarodowa, jak również ich przyjęciu do ONZ w dniu 22 maja 1992 r. towarzyszyła rosnąca międzynarodowa izolacja Jugosławii oraz polityczna presja kierowana pod adresem władz w Belgradzie, mająca na celu zakończenie działań wojennych na obszarze byłej Jugosławii. Co więcej, społeczność międzynarodowa odmówiła uznania ciagłości państwowej FRJ. Mimo deklaracji władz w Belgradzie, iż FRJ jest prawnym i politycznym kontynuatorem międzynarodowej podmiotowości SFRJ, Komisja Arbitrażowa Badintera w swojej opinii z 4 lipca 1992 r. wskazała, iż proces rozpadu SFRJ został zakończony i państwo to już nie istnieje. Brak akceptacji społeczności międzynarodowej dla kontynuacji prawnomiędzynarodowej podmiotowości SFRJ przez FRJ (m.in. przez odrzucenie możliwości kontynuacji członkostwa w ONZ) w istotny sposób skomplikował międzynarodową reprezentację FRJ oraz podważał jej podmiotowość prawnomiędzynarodową ${ }^{81}$. Dodatkowo w dniu 30 maja 1992 r. w celu nakłonienia władz w Belgradzie do wstrzymania pomocy dla bośniackich Serbów Rada Bezpieczeństwa ONZ nałożyła embargo ekonomiczne na Jugosławię, które skutkowało poważnymi stratami dla jugosłowiańskiej gospodarki ${ }^{82}$. Tylko w pierwszym roku

${ }^{79} \mathrm{~W}$ lutym 2002 r., w trakcie procesu przed ICTY, odnosząc się do oskarżeń dotyczących roli Serbii w rozpętaniu wojen na obszarze byłej Jugosławii, S. Milošević wskazał, iż celowo pomija się fakt, że wojna w Bośni i Hercegowinie zakończyła się dzięki negocjacjom w Dayton, w czasie których kluczową rolę odegrała FRJ, zaś prowadzona przez niego „polityka, której celem był pokój”, cieszyła się wówczas szerokim międzynarodowym poparciem i akceptacja. Wskazał też, iż „poszukuje się obecnie odpowiedzialności za rozpetanie wojny po stronie, która popierała pokój. [...] Podżegacze wojenni obarczają odpowiedzialnością za wojnę protagonistów pokoju" - szerzej zob. TICTFY, Trial Transcript, 18 February 2002, http://www.icty.org/x/cases/slobodan_milosevic/trans/en/020218 IT.htm.

${ }^{80}$ A. LeBor, $d z$. cyt., s. 177-179, 184, 193-198.

${ }^{81}$ A. Zimmermann, C. Stahn, Yugoslav Territory, United Nations Trusteeship or Sovereign State? Reflections on the Current and Future Legal Status of Kosovo, „Nordic Journal of International Law" 2001, vol. 70, no. 4, s. 425-440.

${ }^{82}$ C.R. Hume, A Diplomat's View, [w:] Peacemaking in International Conflict..., s. 330. 
od wprowadzenia sankcji import FRJ spadł o 54\%, zaś eksport o $74 \%$, poziom produkcji obniżył się o $42 \%$, nastapił także wzrost cen o $4400 \%{ }^{83}$.

Świadomy pogarszającej się sytuacji międzynarodowej oraz faktycznej niechęci obywateli FRJ do ponoszenia bolesnych kosztów międzynarodowych sankcji gospodarczych (w postaci dramatycznego ubożenia społeczeństwa i hiperinflacji, rosnącego bezrobocia, kryminalizacji życia politycznego i społecznego, ciagłych niedoborów paliwa powodujących przestoje w produkcji, przerw w ogrzewaniu mieszkań itd.) S. Milošević rozpoczął odchodzenie od dotychczas prowadzonej polityki, skłaniając się do wypracowania rozwiązania politycznego kończącego działania wojenne w Bośni i Hercegowinie ${ }^{84}$.

Przygotowany przez społeczność międzynarodową plan pokojowego rozwiązania bośniackiego konfliktu (tzw. plan Vance'a-Owena) zakładał istnienie słabej władzy centralnej oraz podział niepodległego państwa na dziesięć prowincji autonomicznych (tj. trzy serbskie, trzy chorwackie, trzy muzułmańskie i Sarajewo pod zarządem ONZ). Milošević akceptował plan, który faktycznie zabezpieczał dotychczasowe „nabytki” terytorialne Serbów w Bośni i Hercegowinie ${ }^{85}$. Dążąc do uzyskania podobnej akceptacji ze strony coraz bardziej politycznie niezależnych przywódców bośniackich Serbów, prezydent Serbii zdecydował się na wywarcie otwartej presji politycznej. Sporządzony w Belgradzie list, pod którym podpisali się: S. Milošević, prezydent FRJ Dobrica Ćosić i prezydent Czarnogóry Momir Bulatović, zawierał stwierdzenia, iż bośniaccy Serbowie nie maja prawa do „narażania na niebezpieczeństwo oraz sankcje międzynarodowe $10 \mathrm{mln}$ obywateli Jugosławii”, co w oczywisty sposób stanowiło stanowcze wezwanie do akceptacji planu pokojowego ${ }^{86}$. W trybie pilnym do Bośni udał się minister spraw zagranicznych FRJ Vladislav Jovanović, który w dniu 26 kwietnia 1993 r. przedstawił treść listu na forum Zgromadzenia Narodu Serbskiego Bośni i Hercegowiny. Odpowiedź bośniackich Serbów była jednak zdecydowanie negatywna ${ }^{87}$.

Jak trafnie wskazuje A. Uzelac, „by doprowadzić do końca wyczerpujacca wojnę, Milošević decyduje się wywrzeć presję na wodza bośniackich Serbów, Radovana Karadžicia. W środkach przekazu «sprawiedliwa walka narodu serbskiego» ewoluuje stopniowo w "sprawiedliwy pokój»" 88 . W celu wzmocnienia politycznego nacisku na przywódców bośniackich Serbów w dniu 5 maja $1993 \mathrm{r}$. prezydent Serbii udał się do Pale w towarzystwie D. Ćosicia, M. Bulatovicia oraz

${ }^{83}$ The 'Yugoslav' Crisis in International Law. General Issues. Part I, ed. D. Bethlehem, M. Weller, Cambridge 1997, s. XLVI.

${ }_{84}$ A. LeBor, dz. cyt., s. 196-198, 207-218.

85 Tamże, s. 231-233.

${ }_{86}$ Tamze.

87 Tamże; J. Darnton, Defiant Bosnia Serbs Reject Peace Plan, „The New York Times”, 26 IV 1993, http://query.nytimes.com/gst/fullpage.html?res=9F0CE7D8143CF935A15757C 0A965958260.

${ }^{88}$ A. Uzelac, Slobodan Miloszević..., s. 10. 
premiera Grecji Konstantinosa Mitsotakisa i na forum Zgromadzenia jednoznacznie opowiedział się za przyjęciem planu Vance'a-Owena. Mimo próśb i ostrzeżeń S. Miloševicia, który wskazywał, że „nie ma alternatywy dla decyzji, która przynieść może pokój”, po burzliwych i wielogodzinnych obradach, nad ranem 6 maja Zgromadzenie Narodu Serbskiego Bośni i Hercegowiny w głosowaniu odrzuciło plan pokojowy (przeciw było 80\% deputowanych), otwarcie sprzeciwiajac się woli prezydenta Serbii ${ }^{89}$. Jak podsumowuje A. Uzelac, „w efekcie pragmatyczny Milošević zrozumiał, że Karadžić jest największym dlań zagrożeniem politycznym"

Wydarzenia w Pale pokazały, iz dotychczasowe relacje między przywódcami z Belgradu i Pale uległy poważnej zmianie, a prezydent Republiki Serbskiej w Bośni, mimo pozorów współpracy, po prostu odmawiał wykonywania poleceń prezydenta Serbii. Doskonale obrazuje ten fakt A. Uzelac, wskazując, iż „w oryginalnym scenariuszu rola, która przeznaczono Radovanowi Karadžiciowi, przywódcy Serbów bośniackich, była identyczna z rolą przeznaczona liderowi chorwackich Serbów - epizodyczna. Jego zadaniem było całkowite podporządkowanie się Wodzowi i kierowanie bośniackimi Serbami według wskazówek udzielanych z Belgradu. Milošević wtedy jeszcze nie był świadomy, że ten epizodyczny aktor ma własną wizję swej roli. Swoje ambicje. Swoje mapy i swoje procenty. I że od nich nie odstapi [...]. Nieszczęśliwy naród serbski otrzymuje więc jeszcze jednego wodza. Psychiatrę i poetę"91.

Tymczasem sytuacja międzynarodowa stawała się coraz bardziej niekorzystna. Kiedy w dniu 1 marca 1994 r. w wyniku presji Stanów Zjednoczonych w Waszyngtonie podjęto decyzję o utworzeniu federacji Muzułmanów i Chorwatów w Bośni i Hercegowinie, S. Milošević musiał być w pełni świadomy, że dotychczasowa wojna „wszystkich ze wszystkimi” kończy się i powstaje jednolity front wojskowy wspierany przez Stany Zjednoczone, skierowany przeciw bośniackim Serbom ${ }^{92}$. Także wydarzenia w Chorwacji wskazywały, że zbliża się moment decydującego militarnego rozstrzygnięcia. Dozbrojona (mimo istnienia międzynarodowego embarga) i przeszkolona w wyniku nieformalnego wsparcia (m.in. Stanów Zjednoczonych) armia Chorwacji (HV) przeprowadziła w maju i sierpniu 1995 r. dwie zorganizowane operacje wojskowe, które doprowadziły do

89 R. Bilski, Nie strzelajcie do nocnego ptaka. Batkany 1991-1998, Warszawa 1998, s. 31-39: S.P. Ramet, The Three Yugoslavias. State-Building and Legitimation, 1918-2005, Washington 2006, s. 441; TICTFY, Trial Transcript, 12 September 2003, http://www/icty.org/ x/cases/slobodan_milosevic/trans/en/030912IT.htm.

90 A. Uzelac, Slobodan Miloszević..., s. 10

${ }^{91}$ Tamże.

92 I. Oliver, War \& Peace in the Balkans. The Diplomacy of Conflict in the Former Yugoslavia, London 2005, s. 84-85; S.L. Woodward, Balkan Tragedy. Chaos and Dissolution after the Cold War, Washington 1995, s. 243; D.N. Gibbs, First Do Not Harm. Humanitarian Intervention and the Destruction of Yugoslavia, Nashville 2009, s. 155. 
likwidacji Serbskiej Republiki Krajiny w Chorwacji i fali serbskich uchodźców. W wyniku operacji „Burza” (4-8 sierpnia 1995 r.) do Bośni i Hercegowiny oraz Jugosławii napłynęło ok. 150-200 tys. Serbów ${ }^{93}$. Mimo iż S. Milošević oficjalnie potępił działania władz w Zagrzebiu, nie zdecydował się na wysłanie VJ dla ratowania parapaństwa chorwackich Serbów, świadomy międzynarodowych konsekwencji rozpoczęcia działań wojennych przeciwko niepodległej Chorwacji ${ }^{94}$.

W sytuacji rosnącej krytyki międzynarodowej, pogarszającej się sytuacji militarnej oraz trudnej sytuacji wewnętrznej w FRJ Milošević kontynuował naciski na przywódców bośniackich Serbów, domagając się od nich zakończenia działań wojennych. Jak stwierdza A. Uzelac: „SSprawiedliwy pokój» w ciąu roku 1994 przerasta w "pokój bez alternatywy»" ${ }^{5}$. W dniu 7 czerwca 1994 r. prezydent FRJ Zoran Lilić w wywiadzie prasowym wysuną pod adresem bośniackich Serbów jednoznaczne ostrzeżenie wskazując, iż „10 mln obywateli Jugosławii nie może pozostawać zakładnikiem jakiegokolwiek przywódcy, który pochodzi z terytorium Jugosławii, Republiki Serbskiej czy Republiki Serbskiej Krajiny"96.

Dążacy do zakończenia wojny w Bośni i Hercegowinie S. Milošević poparł zatem kolejna propozycję pokojową w postaci tzw. planu Grupy Kontaktowej, tworzonej przez Stany Zjednoczone, Wielką Brytanię, Francję, Rosję i Niemcy. Plan ten zakładał niepodległość Bośni oraz faktyczny podział państwa, gwarantujący 51\% terytorium dla Federacji Bośni i Hercegowiny oraz 49\% dla Republiki Serbskiej ${ }^{97}$. Kiedy w dniu 3 sierpnia 1994 r. zgromadzenie bośniackich Serbów zignorowało stanowisko FRJ i odrzuciło plan Grupy Kontaktowej, Jugosławia zerwała wszelkie stosunki z Republiką Serbską wprowadzając wobec niej sankcje ekonomiczne (nie dotyczyły one jednak żywności i leków). Sankcje te - przynajmniej oficjalnie - obejmowały również blokadę dostaw uzbrojenia, co redukowało możliwość kontynuacji działań wojennych przez bośniackich Serbów. Dążąc do złagodzenia sankcji nałożonych na Jugosławię władze w Belgradzie pozwoliły także na weryfikację stosowania się FRJ do międzynarodowych sankcji nałożonych na Republikę Serbską przez obserwatorów ONZ, którzy monitorowali granice Jugosławii i Bośni. Dodatkowo w jugosłowiańskich mediach przywódcy Serbów z Bośni i Hercegowiny poddawani byli ostrej i daleko posuniętej krytyce,

${ }^{93}$ N. Thomas, K. Mikulan, The Yugoslav Wars (1)..., s 55-56; I. Oliver, dz. cyt., s. 88-90; M. Waldenberg, Rozbicie Jugostawii. Od separacji Stowenii do wojny kosowskiej, Warszawa 2003, s. 140-151: M. Bromley, United Nations Arms Embargoes. Their Impact on Arms Flows and Target Behaviour. Case Study: Former Yugoslavia, 1991-96, Stockholm 2007, http://books.sipri.org/files/misc/ UNAE/SIPRI07UNAEYug.pdf.

${ }_{94}$ N. Thomas, K. Mikulan, The Yugoslav Wars (1)..., s. 56; A. LeBor, dz. cyt., s. 219, $227-230$.

${ }_{95}$ A. Uzelac, Slobodan Miloszević..., s. 10.

${ }^{96}$ A. LeBor, dz. cyt., s. 233-234.

${ }_{97}$ Tamże; A. Pavković, The Fragmentation of Yugoslavia. Nationalism and War in the Balkans, London 2000, s. 175. 
co stanowiło istotną różnicę od wcześniejszej kierowanej pod ich adresem patriotycznej retoryki ${ }^{98}$.

Mimo to kontrolujący większość terytorium państwa bośniackiego Serbowie w dalszym ciąu pozostawali niechętni do zakończenia wojny. W maju $1995 \mathrm{r}$. w odpowiedzi na selektywne lotnicze uderzenia NATO w potencjał militarny VRS Serbowie zaczęli brać do niewoli personel sił pokojowych ONZ. Zapewne w wyniku bezpośrednich nacisków S. Miloševicia, do połowy czerwca 1995 r. ponad 400 członków personelu UNPROFOR zostało uwolnionych ${ }^{99}$. Kolejnym wydarzeniem, które godziło w międzynarodowy wizerunek Jugosławii, była szokująca i brutalna zbrodnia w Srebrenicy, dokonana przez VRS w lipcu 1995 r.

Ocena ewentualnego zaangażowania FRJ w wydarzenia w Srebrenicy od lat budzi szereg wątpliwości i sprzecznych głosów. Z jednej strony zasadne wydaje się przypuszczenie, że dbający o wizerunek „orędownika pokoju” i domagający się zniesienia międzynarodowych sankcji gospodarczych nałożonych na FRJ S. Milošević nie mógł politycznie skorzystać na zamordowaniu ponad 8 tys. muzułmańskich jeńców w Srebrenicy ${ }^{100}$. Z drugiej strony wskazane już bliskie powiązania między VRS i VJ budzą szereg pytań nt. rzeczywistego stanu wiedzy polityków w Belgradzie o planach i działaniach armii gen. R. Mladicia ${ }^{101}$.

Trudności z udzieleniem jednoznacznej odpowiedzi dostrzec można także w orzecznictwie sądów międzynarodowych. Jakkolwiek w akcie oskarżenia S. Miloševicia przed ICTY zawarty jest zarzut współudziału w ludobójstwie (w tym także expressis verbis w Srebrenicy), w lutym 2007 r. w wyroku w sprawie Bośnia $i$ Hercegowina v. Serbia $i$ Czarnogóra MTS, który rozpatrywał zarzut udziału FRJ w zbrodniach popełnionych na terytorium Bośni i Hercegowiny, wskazał, że „Serbia nie dopuściła się ludobójstwa poprzez działania jej organów lub osób, których działania wiążą jej odpowiedzialność zgodnie z międzynarodowym prawem zwyczajowym [...]. Serbia nie spiskowała w celu popełnienia ludobójstwa [...]. Serbia nie jest winna współudziału w ludobójstwie", stwierdzając na koniec, iż „Serbia pogwałciła zobowiązanie do zapobieżenia zbrodni ludobójstwa, które ciążyo na niej zgodnie $\mathrm{z}$ treścią Konwencji w sprawie zapobiegania i karania zbrodni ludobójstwa w odniesieniu do ludobójstwa, jakie miało miejsce w Srebrenicy w lipcu 1995 r.”102

98 A. LeBor, $d z$. cyt., s. 234; M. Bromley, dz. cyt., s. 8-12; C.R. Hume, dz. cyt., s. 331; R. Bideleux, I. Jeffries, The Balkans. A Post-Communist History, Abingdon 2007, s. 349; A.K. Talentino, Bosnia, [w:] The Costs of the Conflict. Prevention and Cure in the Global Arena, ed. M.E. Brown, R.N. Rosecrance, Lanham 1999, s. 38.

${ }_{99}$ A. LeBor, dz. cyt., s. 237.

${ }_{100}$ Tamże, s. 234-238.

101 Tamże.

102 TICTFY, Case No. IT-02-54-T...; International Court of Justice, Case Concerning the Application... 
Wyrok, w którym MTS stwierdził, iż w świetle prawa międzynarodowego Serbia nie ponosi bezpośredniej odpowiedzialności za zbrodnie popełnione w czasie wojny w Bośni i Hercegowinie, wzbudził szereg wątpliwości ${ }^{103}$. Jak zauważył były sędzia ICTY Antonio Cassese: „Aby rozstrzygnąć, czy Mladić, planując masakrę i dokonując jej, działał w imieniu Serbii, sąd zażądał dowodu, że funkcjonariusze państwa serbskiego dawali mu konkretne «instrukcje» popełnienia ludobójstwa. Oczywiście takich instrukcji nigdy nie znaleziono. Jakby nie wystarczało dowieść, że dowództwo armii bośniackich Serbów było opłacane przez Serbię i ściśle powiązane z politycznym i wojskowym kierownictwem Serbii. [...] Zasadniczy problem z decyzja MTS to nierealistycznie wysoko podniesiona poprzeczka dowodu, że Serbia prawnie odpowiada za ludobójstwo"104.

Bezkompromisowość bośniackich Serbów powodowała zatem, że dążący do zakończenia wojny i zniesienia międzynarodowych sankcji S. Milošević nie miał łatwego zadania. Jak wskazywał wówczas Čedomir Štrbac, dyrektor Departamentu Studiów i Planowania w Ministerstwie Spraw Zagranicznych FRJ: „Misja prezydenta Miloševicia jest bardzo trudna i delikatna. Musi się liczyć nie tylko $\mathrm{z}$ naciskami z zewnątrz, ale i z opinią różnych sił wewnętrznych. [...] Z jednej strony zachodnie media oskarżaja Miloševicia o spiskowanie z Karadžiciem, a z drugiej strony wewnętrzna opozycja zarzuca mu prowadzenie antynarodowej polityki i zdradę sprawy Serbów"105.

Wysiłki prezydenta Serbii wzmocniła niekorzystna dla VRS zmiana sytuacji na frontach Bośni i Hercegowiny. W sierpniu 1995 r. rozpoczęła się skoordynowana ofensywa HV, oddziałów Chorwackiej Rady Obrony (HVO) - tj. armii bośniackich Chorwatów - oraz Armii Republiki Bośni i Hercegowiny (ARBiH), w wyniku której VRS została zmuszona do chaotycznego odwrotu ${ }^{106}$. Dodatkowo po kolejnym ataku moździerzowym VRS na Sarajewo w dniu 28 sierpnia 1995 r., który doprowadził do śmierci 37 osób cywilnych (kolejne 88 zostało rannych), NATO rozpoczęło powietrzną kampanię militarną (operacja „Deliberate Force”), która w poważnym stopniu zniszczyła potencjał wojskowy armii bośniackich Serbów. Wydarzenia te pokazały po raz pierwszy od rozpoczęcia wojny, że może dojść do militarnej klęski VRS, w efekcie czego Republika Serbska mogłaby w szybkim czasie podzielić los Republiki Serbskiej Krajiny, zaś jej upadek z pewnością oznaczałby napływ do Jugosławii kolejnych setek tysięcy serbskich uchodźców, potencjalne niepokoje społeczne oraz groźbę odsunięcia od władzy polityków odpowiedzialnych za konflikty zbrojne i międzynarodową marginalizację Jugosławii oraz drastyczne

${ }^{103}$ Szerzej zob.: A. Skieterska, Serbia niewinna?, „Gazeta Wyborcza”, 27 II 2007, s. 10; D. Warszawski, Kto winien Srebrenicy, ,Gazeta Wyborcza”, 28 II 2007, s. 10.

104 A. Cassese, Sadowa masakra Srebrenicy, , Gazeta Wyborcza”, 1 III 2007, s. 19.

${ }^{105}$ S. Grzymski, Nasza ojczyzna nadal jest Jugosławia, ,Rzeczpospolita”, 1 VIII 1995, s. 6.

${ }^{106}$ N. Thomas, K. Mikulan, The Yugoslav Wars (2)..., s. 26-29; I. Oliver, dz. cyt., s. $83-91$. 
pogorszenie warunków życia społeczeństwa. W efekcie świadomy politycznych konsekwencji przeciagającego się konfliktu zbrojnego w Bośni i Hercegowinie S. Milošević wymusił na R. Karadžiciu zgodę na rozpoczęcie negocjowania warunków zakończenia wojny w imieniu bośniackich Serbów i po prostu zaakceptował warunki stawiane przez społeczność międzynarodowa ${ }^{107}$.

W czasie negocjacji pokojowych w Dayton w listopadzie 1995 r. to właśnie prezydent Serbii - a zatem przywódca jednej z dwóch republik wchodzacych w skład formalnie neutralnej FRJ - negocjował warunki porozumienia pokojowego kończącego wojnę w Bośni i Hercegowinie. Dla wielu obserwatorów było jednak oczywiste, że jest to rozwiązanie nieprzypadkowe i to właśnie ten serbski polityk pozostaje najwłaściwszą osoba, która powinna brać udział w rokowaniach. Jak stwierdza Ryszard Bilski, „gdy pod koniec 1995 r. podpisywano porozumienie w Dayton, jego bohaterem znów stał się Milošević. Świat był mu wdzięczny za zgodę na przerwanie walk i zaakceptowanie nowej mapy Bośni i Hercegowiny, niezbyt korzystnej dla Serbów. Uważano go wciąż za mocnego człowieka, gwaranta pokoju nie tylko w Jugosławii, ale na całych Bałkanach"108.

Kilka miesięcy po zakończeniu wojny w Bośni i Hercegowinie premier FRJ R. Kontić wskazywał na „znacząca rolę FRJ w rozwiązywaniu kryzysu na obszarze byłej Socjalistycznej Federacyjnej Republiki Jugosławii. Została ona doceniona przez wspólnotę międzynarodowa, a dowodem tego było zawieszenie wszystkich sankcji [...]. Z tą chwilą rozpoczą się proces naszego powrotu do wspólnoty międzynarodowej, powrót do normalności. [...] Powiem krótko: będziemy nadal rzecznikami stabilizacji, ale domagamy się jednakowego traktowania wszystkich stron konfliktu. Celem polityki zagranicznej Belgradu jest normalizacja stosunków z sąsiadami, a także ze wszystkimi państwami, z którymi dawniej współpracowaliśmy"109.

Podpisany w Paryżu w dniu 14 grudnia 1995 r. traktat pokojowy, którego stronami były trzy suwerenne państwa, tj. Bośnia i Hercegowina, Chorwacja oraz Jugosławia, wprowadzał podział niepodległej Bośni według kryteriów etnicznych, co de facto sankcjonowało przeprowadzone wcześniej „czystki etniczne” oraz istnienie uznanej przez społeczność międzynarodową Republiki Serbskiej. W efekcie Dayton, przynajmniej w części, stanowiło spełnienie celu, o jaki walczyli bośniaccy Serbowie, aktywnie wspierani przez oficjalnie neutralną w konflikcie FRJ, i wyraźnie pokazało, że przyjęta przez Serbów strategia siłowej konfrontacji przyniosła wymierne rezultaty ${ }^{110}$.

${ }^{107}$ I. Oliver, $d z$. cyt., s. 83-91; A. LeBor, dz. cyt., s. 238-254; S. Horowitz, From Ethnic Conflict to Stillborn Reform. The Former Soviet Union and Yugoslavia, College Station 2005, s. 201.

${ }_{108}$ R. Bilski, Kocioł bałkański, Warszawa 2000, s. 365.

109 Tenże, Domagamy sie..., s. 7.

110 D.H. Allin, NATO's Balkan Interventions, Oxford 2002, s. 51; M. Griffin, A Stitch in Time: Making the Case for Conflict Prevention, ,,Security Dialogue” 2001, vol. 32, no. 4, s. 482. 
Normalizacja stosunków między Jugosławią a Bośnią i Hercegowiną rozpoczęła się po obaleniu S. Miloševicia (wówczas już prezydenta Jugosławii) w październiku 2000 r. Nowo wybrany prezydent Jugosławii Vojislav Koštunica potwierdził akceptację warunków porozumienia kończącego wojnę w Bośni i Hercegowinie, dwuznacznie stwierdzając jednak, że Bośnia stanowi państwo, które „na zewnątrz stanowi «jakby całość», lecz w istocie składa się z dwóch częśsi. Te dwie części nie sa multietniczne. Gdyby nimi były, to mielibyśmy «Bośnię w Bośni». Politycy znaleźli w Dayton rozwiązanie satysfakcjonujące wszystkie narody: Serbów, Chorwatów i Bośniaków [...]. Sa oni znowu razem, ale i osobno"111. Dopiero w dniu 15 stycznia 2001 r. Jugosławia oraz Bośnia i Hercegowina nawiązały stosunki dyplomatyczne. W dalszym ciagu jednak całkowita normalizacja wzajemnych stosunków pozostaje kwestią przyszłości.

$$
* * *
$$

Jakkolwiek oficjalnie zarówno Serbia, jak i Jugosławia nie były stroną działań wojennych prowadzonych w Bośni i Hercegowinie, aktywny charakter zaangażowania decydentów w Belgradzie w rozwój sytuacji w państwie bośniackim potwierdza treść aktów oskarżenia sporządzonych przez Prokuratora Generalnego ICTY.

Wśród zarzutów kierowanych pod adresem nieżyjącego już S. Miloševicia zawarto stwierdzenia, że jako prezydent Serbii był on bezpośrednio zaangażowany w planowanie, przygotowywanie oraz prowadzenie działań wojennych na obszarze Bośni i Hercegowiny. W dokumencie tym wielokrotnie podkreślono także istnienie „wspólnego przestępczego przedsięwzięcia”, które poza prezydentem Serbii obejmowało innych serbskich polityków i urzędników (Borisav Jović, Radovan Stojičić, J. Stanišić, Franko Simatović), członków korpusu generalskiego i oficerskiego JNA (Veljko Kadijević, Blagoje Adžić, R. Mladić), liderów chorwackich i bośniackich Serbów (Milan Martić, R. Karadžić, Momčilo Krajišnik, Biljana Plavšić), przywódców różnych formacji paramilitarnych (Željko Ražnatović, V. Šešelj) oraz inne osoby. Celem owego „przedsięwzięcia” było przymusowa i trwała zmiana struktury etnicznej zamieszkałych przez Serbów terytoriów Chorwacji oraz Bośni i Hercegowiny, polegająca na siłowej ekspulsji osób narodowości chorwackiej i muzułmańskiej112.

Nie sposób oprzeć się wrażeniu, iż chcący utrzymać się przy władzy S. Milošević początkowo cynicznie wykorzystał, a następnie - faktycznie z tych samych powodów - „zdradził” ideę „Wielkiej Serbii”, co zarzucały mu serbskie środowiska nacjonalistyczne, wskazując, iż porzucił on Serbów w Chorwacji oraz Bośni

\footnotetext{
111 R. Bilski, Złoty dukat dla gospodarza, „Rzeczpospolita”, 16 XII 2000, s. A6.
}

112 TICTFY, Case No. IT-02-54-T.. 
i Hercegowinie ${ }^{113}$. Można przypuszczać, że Milošević dość szybko zdał sobie sprawę z katastrofalnych następstw prowadzonej polityki i po prostu porzucił realizację idei „Wielkiej Serbii” na rzecz przynajmniej częściowo satysfakcjonującego rozwiązania pokojowego. O słuszności powyższej tezy świadczy brak militarnego wsparcia dla upadającej Republiki Serbskiej Krajiny oraz narastające naciski na decydentów w Republice Serbskiej. W efekcie prezydent Serbii w opinii R. Bilskiego „mistrz politycznej ekwilibrystyki” - faktycznie dążył do zakończenia wojny, do której wybuchu w dużym stopniu sam się aktywnie przyczyni1 ${ }^{114}$.

Warto na koniec przytoczyć opinię S. Drakulić, która stwierdza: „Pamiętam, jak zdumieni byli zawsze zachodni ambasadorowie, politycy i wysłannicy po każdym spotkaniu z Mladiciem, Karadžiciem czy Miloševiciem: patrząc prosto w oczy lordowi Owenowi, Carlowi Bildtowi czy Richardowi Holbrooke'owi, ludzie ci kłamali, dawali słowo honoru i podpisywali traktaty, których nie mieli najmniejszego zamiaru przestrzegać. Minęło sporo czasu, zanim ludzie Zachodu sobie to uświadomili"115.

${ }^{113}$ S. Horowitz, dz. cyt., s. 201.

114 R. Bilski, Kociot..., s. 366

115 S. Drakulić, dz. cyt., s. 117. 